\title{
A new species of Fridericia (Oligochaeta : Enchytraeidae) found in a spring in the Sudety mountains (Poland)
}

\author{
E. Dumnicka ${ }^{1}$
}

Keywords : Oligochaeta, Enchytraeidae, Fridericia, new species, Sudety Mts, Poland, spring

A new species, Fridericia dissimilis n. sp., found during a study of the aquatic oligochaete fauna in the region of Snieżnik Massive (Sudety Mts, south-western Poland) is described. The species belongs to the Fridericia group of species characterised by asymmetrical spermathecae with a single diverticulum, but it is easily distinguished from other species by, the enormous size of the gland at the ectal orifice of the spermatheca and the shape of ampulla, andby the shape of the brain and seminal vesicles.

Une nouvelle espèce de Fridericia (Oligochaeta : Enchytraeidae) trouvée dans une source des Monts Sudètes (Pologne)

Mots clés : Oligochaeta, Enchytraeidae, Fridericia, nouvelle espèce, Monts Sudètes,' Pologne, source.

Une espèce nouvelle, Fridericia dissimilis $\mathrm{n}$. sp. a été trouvée au cours d'une étude de la faune d'oligochètes aquatiques dans la région du massif de Śnieżnik (Monts Sudètes, sud-ouest de la Pologne) est décrite. Cette espèce appartient au groupe d'espèces possédant des spermathèques asymétriques avec un seul diverticule, mais elle est faćilémënt différenciée d'autres espèces par les traits suivant : la dimension de la glance située à la base du canal de la spermathèque ainsi que, par la forme du «cerveau» et de la vésicule séminale.

\section{Introduction}

The knowledge of the aquatic oligochaetes fauna of Sudety Mts is relatively poor. The first study: was car-m ried out by Hrabe (1937) on the Śnieżnik Massif ; subsequent reports were published by Kasprzak (1973 a, b). The new species described herein, was found during a survey of the oligochaete fauna inhabiting the surface and subterranean waters in the same region.

The genus Fridericia is mainly found in terrestrial habitats, but some species live on the bottom of water bodies (Kasprzak 1986), especially in smäll ones like springs or streams, where the contact with the surroun-

\footnotetext{
1. Karol Starmach Institute of Freshwater Biology, Polish Academy of Sciences, S lawkowska 17, 31-016 Kraków, Poland.
}

ding soils is large. The search for Fridericia dissimilis n. sp. in the soil around the Kletno spring did not yield results. So far, this species has been found in the aquatic environment only. This"spring. dries up in the dry years, and perhaps at such times Fridericia dissimilis lives in the soil.

\section{Description of species}

Material examined: The holotype and 3 paratypes whole mounted in Canada balsam, are kept in the collection of Karol Starmach Institute of Freshwater Biology, Polish Academy. of Sciences, Kraków.

Further material examined : 3 mature specimens, mounted in Canada balsam.

Etymology : From Latin, dissimilar to other species due to the unusual shape of spermatheca.

Type locality: Sudety Mts, Śnieżnik Massive, near Kletno village, $\left(50^{\circ} 15^{\prime} \mathrm{N}, 16^{\circ} 52^{\prime} \mathrm{E}\right)$ altitude about $750 \mathrm{~m}$, small, intermittent spring no 2 (according to 


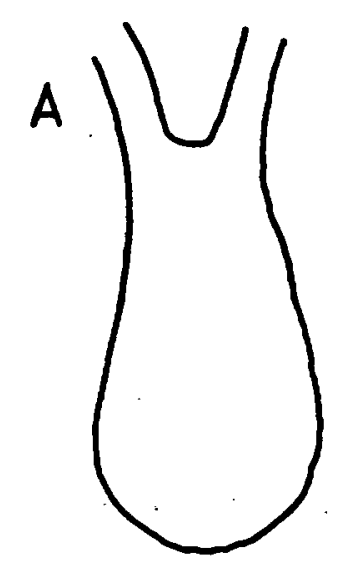

$100 \mu \mathrm{m}$
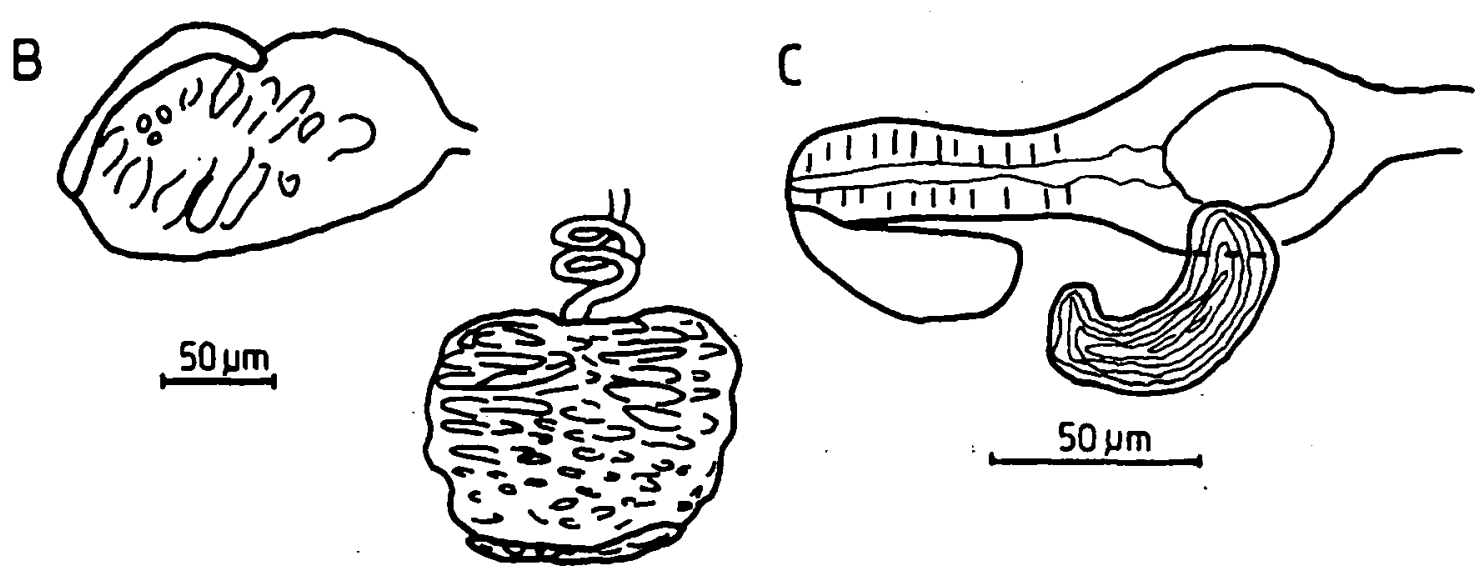
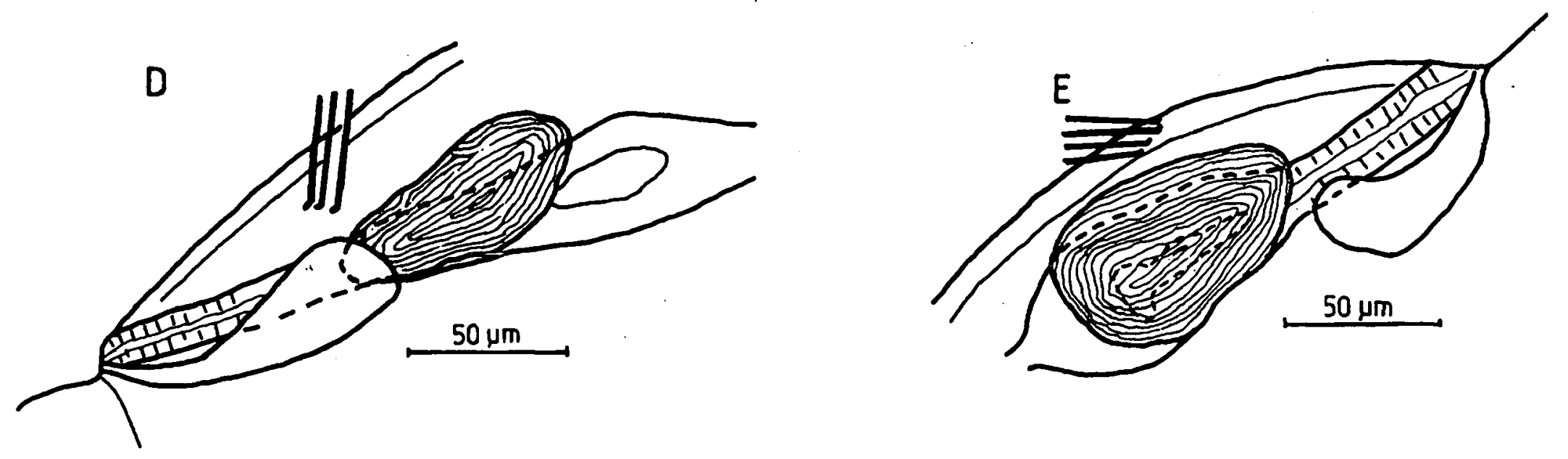

Fig. 1. Fridericia dissimilis n. sp. : A - brain, B - sperm funnel, C - E - spermathecae, C - lateral view, D - E dorsal view. Fig. 1. Fridericia dissimilis n. sp. : A - cerveau, B - spermathèques, C - vue latérale, D-E - vue ventrale.

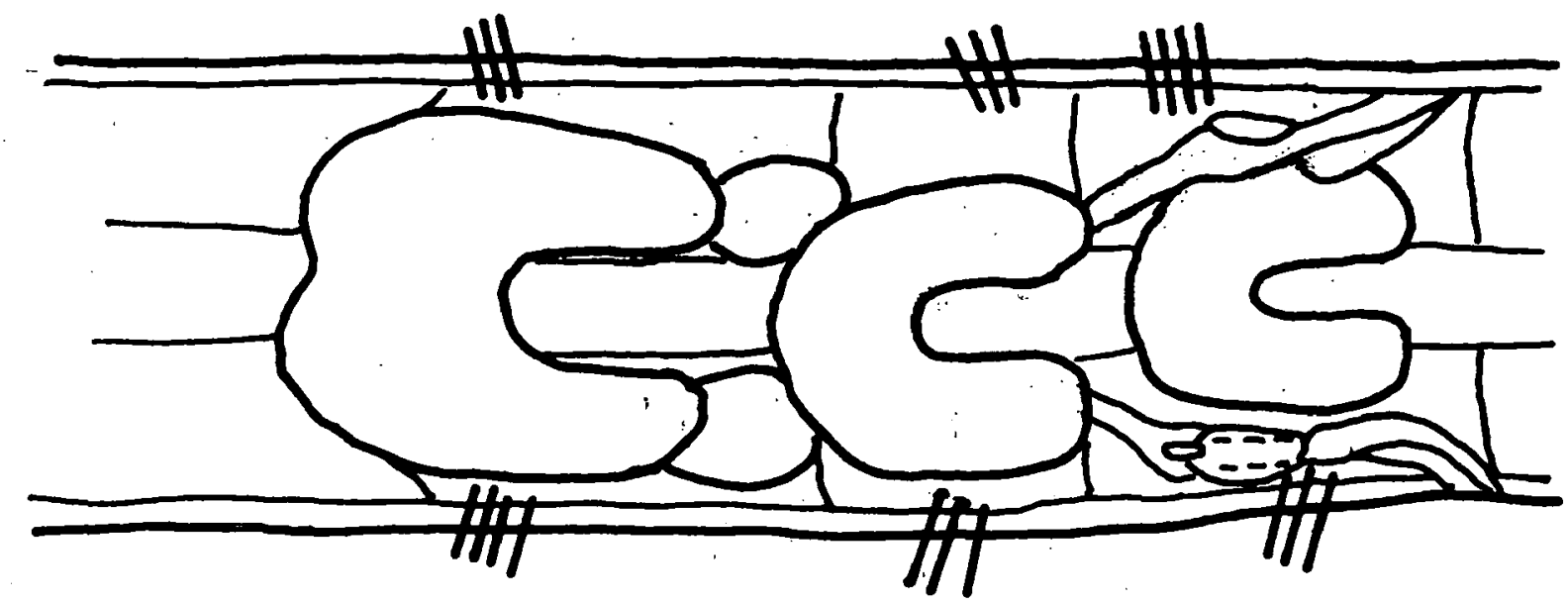

Fig. 2. Fridericia dissimilis n. sp. : location and shape of pharyngeal glands (schematic).

Fig. 2. Fridericia dissimilis n. sp. : emplacement et dessin schématique des glandes pharyngiennes. 
Table1. Distinguishing characters of Fridericia species with one spermathecal diverticulum.

Tableau 1. Caractères distinctifs des espèces de Fridericia avec spermathèque à un seul diverticule.

\begin{tabular}{|c|c|c|c|c|c|c|c|}
\hline Species & setal formula & $\begin{array}{l}\text { peptone- } \\
\text { phridia }\end{array}$ & $\begin{array}{l}\text { glands at ectal } \\
\text { orifice of } \\
\text { spermatheca }\end{array}$ & $\begin{array}{l}\text { ectal duct of } \\
\text { spermatheca }\end{array}$ & $\begin{array}{l}\text { sperm } \\
\text { funnel } \\
\text { width: } \\
\text { length }\end{array}$ & $\begin{array}{l}\text { seminal } \\
\text { vesicles }\end{array}$ & $\begin{array}{l}\text { septal } \\
\text { glands }\end{array}$ \\
\hline $\begin{array}{c}F . \text { monopera } \\
\text { Cognetti }\end{array}$ & $2-2: 2-2$ & $\begin{array}{l}\text { unbranched } \\
\text { (type a) }\end{array}$ & $\begin{array}{l}1 \text { large gland } \\
1 / 3 \text { of length } \\
\text { of ectal duct }\end{array}$ & $\begin{array}{l}\text { short, } 1.5 \text { times } \\
\text { longer than } \\
\text { diverticulum }\end{array}$ & $1: 1-1.5$ & $?$ & $?$ \\
\hline $\begin{array}{l}\text { F. anomala } \\
\text { Košel }\end{array}$ & $2-2: 2-2$ & $\begin{array}{l}\text { unbranched } \\
\text { (type a) }\end{array}$ & 1 small gland & $\begin{array}{l}\text { narrow, long, } \\
\text { 3-3.5 times longer } \\
\text { than diverticulum }\end{array}$ & $1: 1.5-2$ & absent & $\begin{array}{l}\text { all pairs } \\
\text { united } \\
\text { dorsally }\end{array}$ \\
\hline $\begin{array}{l}F . \text { singula } \\
\text { Niel. \& Christ. }\end{array}$ & $4-4,2: 4-4,2$ & $\begin{array}{l}\text { unbranched } \\
\text { (type a) }\end{array}$ & absent & $\begin{array}{c}\text { narrow, } \\
3 \text { times longer } \\
\text { than diverticulum }\end{array}$ & $1: 1.5$ & $\begin{array}{c}\text { well } \\
\text { developed }\end{array}$ & $?$ \\
\hline $\begin{array}{l}\text { F. asymmetricoides } \\
\text { Kasprzak }\end{array}$ & $\begin{array}{r}3,4-4,3,2: \\
2,3,4-4,2\end{array}$ & $\begin{array}{l}\text { branched } \\
\text { (type c) }\end{array}$ & absent & $\begin{array}{l}\text { medium, } 2-2.5 \\
\text { longer than } \\
\text { diverticulum }\end{array}$ & $1: 2-3$ & absent & $\begin{array}{l}\text { third pair } \\
\text { elongated } \\
\text { with ventral } \\
\text { lobes }\end{array}$ \\
\hline $\begin{array}{l}\text { F. deformis } \\
\text { Möller }\end{array}$ & $\begin{array}{c}2,3,4-2,3,4 \\
3,4-2,3,4\end{array}$ & $\begin{array}{l}\text { unbranched } \\
\text { (type a) }\end{array}$ & 1 big gland & $\begin{array}{l}\text { short, wide } \\
\text { 1.5-2 times longer } \\
\text { than diverticulum }\end{array}$ & $1: 3$ & $\begin{array}{l}\text { present in } \\
\text { XII }\end{array}$ & $\begin{array}{l}\text { united } \\
\text { dorsally } \\
\text { in IV }\end{array}$ \\
\hline F. dissimilis sp.n. & $\begin{array}{c}3,4-2,3: \\
3,4,(5)-2,3,4\end{array}$ & $\begin{array}{l}\text { unbranched } \\
\text { (type a) }\end{array}$ & $\begin{array}{l}1 \text { enormously } \\
\text { big, same } \\
\text { length as ectal } \\
\text { duct }\end{array}$ & $\begin{array}{l}\text { short, wide about } \\
\text { the same length as } \\
\text { diverticulum }\end{array}$ & $1: 1-1.5$ & $\begin{array}{l}\text { small in } \\
\mathrm{XI}\end{array}$ & $\begin{array}{l}\text { united dor- } \\
\text { sally, last } \\
\text { with ventral } \\
\text { lobes }\end{array}$ \\
\hline
\end{tabular}

Cieżkowski 1989), bottom clayey with stones. Leg. E. Dumnicka, collected 2 May 1996.

The following description is based on material preserved with $4 \%$ formalin, then stained in alcohol. Length of body $5-7 \mathrm{~mm}$, number of segments $32-38$, diameter of body in segment $\mathrm{V}: 270-290 \mu \mathrm{m}$, in clitellar segments $310-350 \mu \mathrm{m}$. Setae straight, with a well developed ental hook, $40-46 \mu \mathrm{m}$ in the preclitellar segments and $43-51 \mu \mathrm{m}$ long in the postclitellar segments, within a bundle the inner ones are shorter and a little thinner than the outer ones. The setal formula is as follows : $3,4-2,3: 3,4(5)-2,3,4$. Sometimes there are two setae in ventral bundles of segment II and terminal segments.

In preclitellar segments cutaneous glands small, irregularly outlined, arranged in 3 - 4 transverse rows per segment. In the postclitellar part of body such glands are smaller and less visible. Brain two times longer than wide (Fig. 1A), concave anteriorly and rounded or almost flat posteriorly. Peptonephridia seems to be unbranched (type a), ending in the segment $V$. Pharyngeal glands at 4/5 - 6/7, all pairs united dorsally, last pair elongated, with well developed ventral lobes (Fig. 2). Chloragogen cells from segment V. Chylus cells present from segment XV. Coelomocytes nucleated, look granular,18 - $25 \mu \mathrm{m}$ long, with small nuclei ; anucleate celomocytes very shiny, $5-7 \mu \mathrm{m}$ long, abundant in postclitellar segments.

Clitellum over XII - 1/2 XIII, a little elevated, with gland cells arranged irregularly. Seminal vesicle small, occupying a limited part of segment XI. Sperm funnels large, barrel shaped, with collar of about the same width as funnel (Fig.1B). Heads of the spermatozoa 80 $100 \mu \mathrm{m}$ long, but in some specimens longer and a little twisted. Sperm duct tightly coiled. Penial bulb small (diameter : $70-90 \mu \mathrm{m}$ ). One gland, as long as ectal duct, present at the ectal orifice of each spermatheca (Fig. 1C-E). Ectal duct of about the same length as am- 
pulla; most often ampullae are thick-walled, sac-shaped, but in some cases they are a little reduced, oval and very small (Fig. 1D). Sperm was never observed in ampullar lumen, where sometimes mucus concentrations were present. Only one diverticulum present, completely filled with sperm, arising from ectal part of the ampulla . Diverticulum is oval-shaped, or more elongated with sperm coiled in almost regular ball. Ampulla passes gradually into a short ental duct of the same width as ectal duct. Ental ducts join oesophagus separately.

\section{Discussion}

Fridericia dissimilis $\mathrm{n}$. sp. belongs to a group of species, characterised by having the spermatheca with one asymmetrical diverticulum. This group consists of six species (including the new one). The six species differ from each other by some morphological and anatomical structures (see Table 1), but the main distinguishing feature is the shape of the spermatheca. Three species - F. monopera Cognetti 1903, F anomala Kosel, 1975 and $F$. deformis Möller, 1971 - have a single gland at the ectal orifice of the spermatheca, but in $F$. dissimilis n. sp. this gland is distinctly larger than in these other species. The shape of the ampulla and diverticulum and the proportions between particular parts of the spermatheca are also characteristic for each of these species (Table 1). In $F$. asymmetricoides Kasprzak, 1972 and $F$. singula Nielsen \& Christensen, 1961 diverticulum looks like a protrusion of the ampulla. The remaining species ( $F$. deformis, $F$. anomala and $F$. monopera) have the diverticulum freely floating in the coelom, as in $F$. dissimilis but, $F$. anomala, like $F$. singula differs from the new species by having the ental ducts of the spermathecae united before joining the oesophagus ; $F$. monopera has a long, finger- shaped diverticulum and $F$. deformis has the sperm coiled like a figure eight.

Accompanying fauna : Larvae of Plecoptera and Chironomidae, Oligochaeta : Cognettia sphagnetorum, Mesenchytraeus armatus and Enchytraeidae genn. spp. juv. In the soil around the spring : Enchytraeidae genn. spp. juv., Henlea spp., Cognettia sphagnetorum, Fridericia sp. juv.

\section{References}

Ciezkowski W. 1989. - Badania hydrogeologiczne obszaru krasow go Masywu Śnieznika. In : Jaskinia Niedźwiedzia w Kletnie. Badania i udostępnianie. A. Jahn, S. Kozłowski \& T. Wiszniowska (eds), Wrocław, Ossolineum : 180-201. (In Polish, English summary).

Hrabe S. 1937. - Prispevek k poznani zvireny Kralickeho Snežniku. Sbornik Klubu prirod. v Brne, 20 : 1-10 (In Czech, German summary).

Kasprzak K. 1972 - A new species of Enchytraeidae (Oligochaeta) found in the National Park of Great Poland. Bull. Acad. pol. Sci., Sr. Sci. Biol., Cl. II., 20 (8) : 563-566.

Kasprzak K. 1973 a. - - Notatki o faunie skaposzczetów (Oligochaeta) Polski, I. Fragm. Faun., 18 : 405-434 (In Polish, English summary).

Kasprzak K. 1973 b. - Notatki o faunie skapposzczetów (Oligochaeta) Polski, I. Fragm. Faun., 19 : 1 - 19 (In Polish, English summary).

Kasprzak K. 1986. - Skapposzczety wodne i glebowe, II. Rodzina : Wazonkowce (Enchytraeidae). Klucze do oznaczania bezkręgowców Polski, t. 5, PWN, pp 366 (In Polish).

Kosel V. 1975. - - A new species of Fridericia (Oligochaeta, Enchytraeidae) with asymmetric spermatheca from Slovakia (Western Carpathians). Biologia, $30: 333-336$.

Möller F. 1971. - Systematische Untersuchungen an terricolen Enchytraeidae einiger Grünlandstandorte im Bezirk Potsdam. Mitt. Zool. Mus. Berlin, 47 : 131-167.

Nielsen C. O. \& Christensen B. 1961. - The Enchytraeidae, critical revision and taxonomy of european species. Supplement 1. Natura Jutlandica, $10: 1-23$. 